\title{
Concept Maps: Evaluation Models for Educators
}

\author{
Edson Coutinho* \\ Business Department, Centro Universitário da FEI, Sáo Bernardo do Campo, Brazil \\ *Corresponding author: coutinho_ed@hotmail.com \\ Received September, 17, 2014; Revised November 20, 2014; Accepted December 04, 2014
}

\begin{abstract}
Concept maps are graphical tools for organizing and representing knowledge. This paper aims to present seven models in order to assess concept maps of students in classroom. These assessment models provide teachers (or professors) with a tool to evaluating concept maps and reinforcing the learning method instead of traditional teaching methods present in some higher educational institutions, such as in Brazil. To build this paper, this author made a deep research in national and international journals in order do find assessment models of concept maps. This paper does not propose to debate or discuss which model is considered the most suitable for the assessment. However it is possible to observe that the models have some "common" dimensions of evaluation, even though three of them have a larger number of dimensions or assessment. Thus, it is up to educators to choose the most suitable model for their needs and also considering the scope of each course. Future studies should put in practice some of these models with purpose to foment this knowledge area.
\end{abstract}

Keywords: concept maps, graphical tools, learning method

Cite This Article: Edson Coutinho, “Concept Maps: Evaluation Models for Educators.” Journal of Business and Management Sciences, vol. 2, no. 5 (2014): 111-117. doi: 10.12691/jbms-2-5-4.

\section{Introduction}

People organize meanings regarding the knowledge or content in a more efficient way when they consider learning more general and inclusive about a particular subject. In this case, the concept maps emerge as a possibility to facilitate meaningful learning through diagrams that can be drawn by means of key concepts. As a result, the concept maps have become an educational resource as demonstrated in Novak and Cañas [12] and Oliveira and Frota [15] studies. For these authors the concept maps are a sort of tool for intervention of a teacher (or professor) in their theoretical classes and in practical activities. The concept maps may be used by students to take notes, to solve problems, to plan studies, to organize reports, to study for exams and to identify and integrate topics of a subject. For educators, the concept maps may help in teaching a new topic in a course, to enhance the understanding from the moment the students make connections and a hierarchy of concepts through the tree structure and the learning assessment. In summary, the conceptual maps allow an approach of the students to the concepts studied by them, from a methodology focusing on student learning and not the educator teachings.

In general, the concept maps are intended to understand how the students connect and line up the concepts presented in the classroom. Thus, a question comes out: "how could an educator evaluate a concept map drawn by a student?" This paper aim to present seven models for assessment of concept maps in order to understand how the students organize in their cognitive the concept of a given subject. This paper does not propose to debate or discuss which model is considered the most suitable for the assessment. It is up to educators to choose the most suitable model for their needs and also considering some constraints such as: course characteristics, subject content, age of students and, also, the purpose of the educational institution. The insights for the development of this paper emerged from the implementation of a Pedagogical Course Project (PCP) based on the competency-based education in an undergrad course of Business in a University located in São Paulo State. In this PCP the concept maps is one of the main teaching/learning tools used to assess students in this course. Therefore, the contribution of this paper is towards education, providing educators to use the graphical representation of concept map in conducting their classes, mechanisms or assessment alternatives.

\section{What is Concept Map?}

Coined by Joseph Donald Novak in a research program at Cornell University in 1972, concepts maps have been designed with the purpose to monitor and understand changes in children's knowledge regarding the understanding of science [14]. In the course of this program, the researchers interviewed a number of children and had difficulty identifying specific changes in the understanding of scientific concepts. Novak based his research program on Ausubel's theory. Ausubel was a researcher, which developed studies about the cognitive psychology and believed that learning was given through the assimilation of new concepts and propositions into existing concepts and proportional systems already present in the student (or individual). 
This knowledge structure is called cognitive structure of the individual. Having as a challenge to find a better way to represent conceptual understanding of children, Novak came up with the idea that children's knowledge could be represented by a sort of concept maps. Based on this study, Novak designed and presented a new tool and a new opportunity that might be used to comprehend the way individuals organize the concepts cognitively for the understanding of some subject [14].

Novak developed the concept maps from diagrams indicating relationship between concepts or between words that are used to represent other concepts. The concept maps are structures that present the most general concepts down to specific ones; they are used with the purpose of organizing and sequencing content hierarchically [13]. It is worth mentioning that the concept maps cannot and should not be misunderstood with any charts or diagrams, since the purpose is not the same. Concept maps are hierarchically organized from the lines, the relationship among several concepts identified and explained by the individuals, then it is up to them to build cognitively the relationship among concepts and recognize what is more important about a given subject.

The concept maps are based on human cognition, and soon they attracted the interest of educators seeking new alternatives in terms of teaching pedagogies. The concept maps come up to provide the students (at any level) the relationship among concepts that other pedagogies do not provide in order to build a knowledge base about a particular topic or subject. It should be emphasized that there is no way a student establishes relationships among contents, if the basic concepts were not handed out previously and absorbed by them. Here, it is recognized that the contribution of Ausubel becomes so necessary in concept maps through the theory of meaningful learning, where students create links among concepts from the proposition. This researcher brings in the scope of their studies, the perspective that students acquire and organize concepts according to their cognitive structure, in other words, by student's perception [1] and [13].

There is no doubt that the concepts are the basis of human understanding. Fodor [6] does a metaphor when characterize that the concepts are as "atoms" of human thought; Vergnaud [17] argues that the conceptualization is at the "core" of cognitive development. This researcher believes the field of knowledge does not exist without concepts, because human knowledge consists of conceptual fields. Therefore, it is possible to answer the probable question: why are concepts important? Because without them there is no understanding about of anything, there is no cognitive development and the individuals living in a world of concepts.

This same author defines the theory of conceptual fields from three sets: (I) a set of situation that gives sense and constitutes its referent; (II) a set of invariants (the categories of thoughts seen as relevant); propositions understood as being true about the reality; and relationships (the operation of the concept and its meaning); (III) and a set of symbolic representations that form its significant. For Moreira [8] the role of concepts in knowledge constructions is the motto of the conceptual maps and should centralize the activities of teaching and learning, since without them the individual is not able to have understanding of the knowledge and the human cognition would be harmed. In this sense, Ausubel defines that concept learning is given in two ways: one is the construction of concepts from real experiences, learning by discovery and by the comprehension of the other concepts; and second in which new knowledge may be obtained by interaction and "anchoring” under concepts existing in the cognitive structure of the individual.

But, when recognize the meaningful learning? In this case, when individual absorb new information and "anchor" on concepts or relevant propositions pre-existing in their cognitive structure. To be meaningful learning, it is necessary to establish the relationship between the theme that will be learned from the cognitive structure of the individual, by not arbitrary and not literal way. Another possibility is the predisposition that the individual must have in order to link, not arbitrary and not literal, the new subject with the pre-existing concepts, and learning will be distinguished in proportion of their willingness and interest in such relationships. For Novak and Cañas [13], when learning is significant, there is integration which is positive and it results in human enhancement. The human being thinks, acts, and understands the concepts in an integrated way.

Thus, it is possible to draw up an analogy between the meaningful learning and mechanical learning. In the meaningful learning prioritizes some aspects, such as: meant, understanding, transferring ability, relationship among concepts. In the mechanical learning four aspects are prevalent: (I) new content is "stored" in a literal way, without interaction; (II) educators present the concepts; students memorize and "decorate" the concepts; (III) the students generate a dislike to certain content of subjects, mostly those related to field of human sciences; (IV) there is less knowledge kept concerning the content, thus, it will be gradually oblivious. It seems that in mechanical learning, there is low level or no integration of new knowledge with existing ones, resulting in negative consequences: the learned knowledge tends to be soon forgotten; and the structure of knowledge (or cognitive) is not reinforced or modified to clarify misconceptions. Therefore, the learned knowledge has little or no potential for use in training or solving problems.

\section{Concept Maps versus Mind Maps}

Tony Buzan was an English mathematician and psychologist, who created mind maps in the end of the 1960s. Buzan conceived this tool through the observations of the behaviors of students and co-workers who obtained great results using different strategies work and to record their information. Buzan found that they got a great performance from designs, colors, illustrations, symbols and arrows and record of study texts with colored pens. Soon, his study was based on the psychology of learning and Buzan took the view that ideas are not created by the human brain in an organized manner, but rather chaotic; as images seemingly unconnected and random, which will become clear as the neural network of the brain works their relationships with the experiences already witnessed. Before such principle, Buzan created the mind map as a way to draw and structure the thinking that enables quick and deep exploration of ideas, without losing focus of the central theme. It is a graphical representation that designs 
the process of thinking about a particular subject or theme, though a process of stimulating creative thinking, by means planning, summarization and memorization. This technique allows relating a set of ideas that new ideas emerge, reaching a virtuous circle that is the focus of creative thinking [3].

Mind mapping is a powerful tool for recording information non-linearly, ie, drawn from "webs", where the main idea is placed at the center, because the ideas are only described with keywords and illustrated with images, icons and many colors. A mind map must be structured from a "tree" and its "branches"; where the center the main trunks expand each topic from the main subject, and each of them come out "branches" smaller with explanatory details. The "web" format of a mind map enables a strong structure through the bindings created, because while linked each other, can be benefit from the support of the entire structure, helps strengthen and understanding it. When drawn, a mind map is organizing a hierarchy and the topics of subject, while summarizing, providing a global view, showing details and interconnections of the subject and the use of figures and colors can promote memorization of information to "encourage" the brain.

Thereby, the mind map is a useful tool for various applications, such as lecture notes, book summaries, planning lectures, etc. In short, to organize thinking similarly to the way the brain works, because the mind map improvement their skills, promoting the understanding, analysis, interpretation and records of the subject. Buzan and Buzan [4] identified some advantages in using the mind map in relation to the traditional way of record: (I) reductions in record time information, avoiding loss of content; (II) reduction in reading time: easier identify and memorizing information; (III) reduction in time to identify keywords in a text, since the mind map these are words used; (IV) and stronger correlation between the information.

Thus, the question comes out: what are the benefits that mind maps provide for those who use them? First, the organization of knowledge and greater opportunities for application. Second, it is easier and safer to remember about subjects learned previously. Third, focusing on what is relevant and important about some specifically topic. Fourth, increased productivity in the study; and Fifth, the information is more structured and secure. However, the development of mind maps depends on several factors: the resources that the individual has; the individual's goals and needs; the content to be mapped and its current format; the individual's level knowledge about the content; the individual's experience with mind map; and the individual's experience about software to assist them in the drawn and modify the mind maps. In summary, the ideal is the structural unit of mind maps.

This guideline leads to mind maps that are known mnemonic, because: contain keywords that are used to reactive memories; serve to develop memory and make easy the memorization (through technical exercise); and should be easy to remember about some sort of subject. This means that mind maps are as a network of concepts linked and connected, where goals are finding creative associations between the ideas [9] and [18]. There is no doubt that the mind map has the major advantage of freely and without restrictions to prepare the structure; but the main disadvantage is that the links are restricted to simple associations, and is no efficient for an aim which requires an understanding of how a concept is essential to understand the other. For this case, the concept map seems to become more effective. The Figure 1 and Figure 2 shows the structural differences between the two sorts of maps.

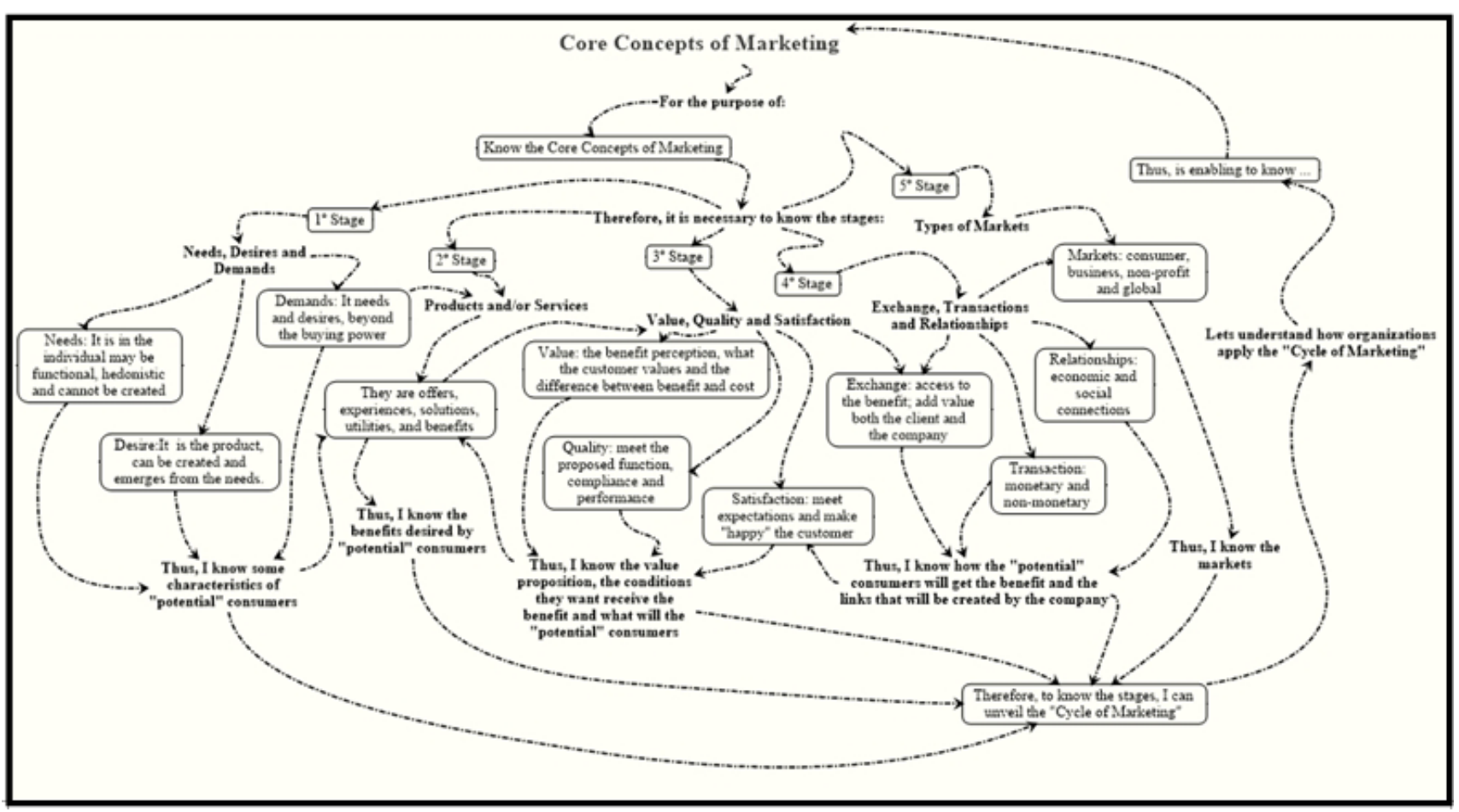

Figure 1. Structure of the Conceptual Maps

Nevertheless, the concept maps may produce to educators the following benefits: (i) summarize and integrate concepts; (ii) make easy the understanding of complex concepts; (iii) understand connections among 
several concepts; (iv) assisting in the teaching and learning process; (v) increase the "role" of students learning; (vi) learn concepts from relations and propositions; (vii) make students to show the understanding about some subject; (viii) organize concepts through hierarchies. However, the challenges are: awareness that concept maps cannot be applied in all classes and the educators must set up criteria to evaluate the maps.

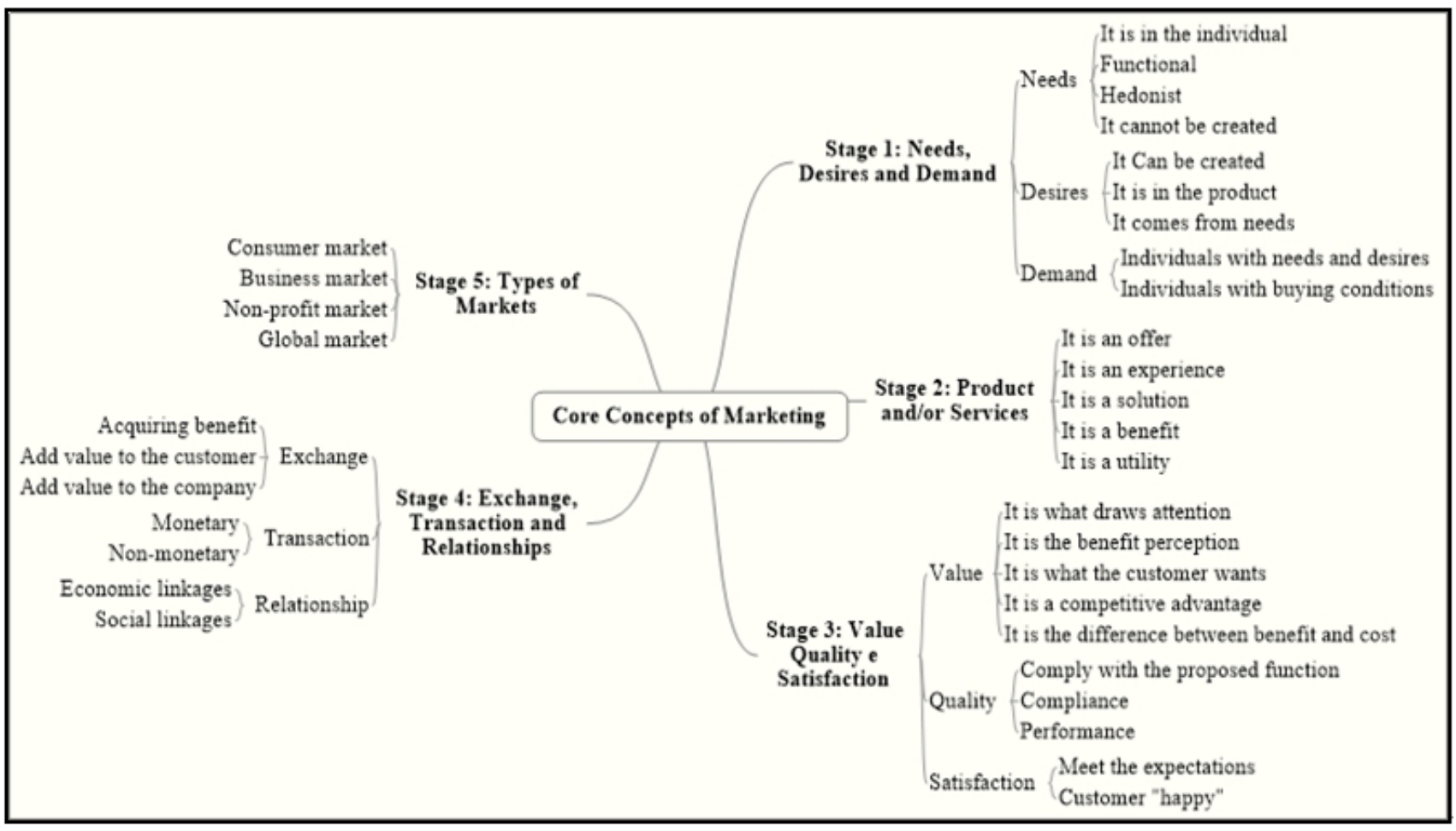

Figure 2. Structure of the Mind Maps

\section{Models for Assessment of the Concept Maps}

One of the biggest challenges of the concept maps is the evaluation process, due to the fact that the map is prepared by the perception of individuals learning. In the other words, there are no maps 100\% incorrect (or wrong).
However, there are some models using assessment scales, for example 0-3; and there are others who assess using: great, good, acceptable and unacceptable. In order to provide a variety of options of assessment, it will be exposed seven alternatives for assessing a concept map. We will not discuss the merits about what is the best or worst, but rather, provide the reference parameters for evaluation.

\section{Table 1. Bartels Model}

\begin{tabular}{|c|c|}
\hline Criteria & Description \\
\hline \multirow{3}{*}{ Concept and Terminology } & $\begin{array}{l}\text { Shows an understanding of the topic's concepts and principles and uses appropriate terminology and notations. } \\
\text { Score } 3 \text { points. }\end{array}$ \\
\hline & Makes many mistakes in terminology and shows a lack of understanding of many concepts. Score 1 point. \\
\hline & Shows no understanding of the topic’s concepts and principles. Score 0 points. \\
\hline \multirow{4}{*}{$\begin{array}{l}\text { Knowledge of the Relationship } \\
\text { among Concepts }\end{array}$} & Identifies all the important concepts and shows an understanding of the relationships among them. Score 3 points. \\
\hline & Identifies important concepts but make some incorrect connections. Score 2 points. \\
\hline & Makes many incorrect connections. Score 1 point. \\
\hline & Fails to use any appropriate concepts or appropriate connections. Score 0 points. \\
\hline \multirow{4}{*}{$\begin{array}{l}\text { Ability to Communicate through } \\
\text { Concept Maps }\end{array}$} & $\begin{array}{l}\text { Constructs an appropriate and complete concept map and includes examples; places concepts in an appropriate } \\
\text { hierarchy and places linking words on all connections. Score } 3 \text { points. }\end{array}$ \\
\hline & $\begin{array}{l}\text { Places almost all concepts in an appropriate hierarchy and assigns linking words to most connections; produces a } \\
\text { concept map that is easy to interpret. Score } 2 \text { points. }\end{array}$ \\
\hline & $\begin{array}{l}\text { Places only a few concepts in an appropriate hierarchy or uses a few linking words; produces a concept map that is } \\
\text { difficult to interpret. Score } \mathbf{1} \text { point. }\end{array}$ \\
\hline & Produces a final product that is not a concept map. Score 0 points. \\
\hline
\end{tabular}

Source: Bartels (1995). 
Table 2. Cronin, Dekker and Dunn Model

\begin{tabular}{|c|c|}
\hline Criteria & Description \\
\hline Concepts & $\begin{array}{l}\text { Concepts are objects, events, situations or properties of things that designated by a label or symbol. Score } 1 \text { point, for each } \\
\text { concept that is connected to at least one other concept by a proposition }\end{array}$ \\
\hline Grouping & $\begin{array}{l}\text { Grouping ate the ways concepts can be linked or joined together. There are three types of grouping: (I) point grouping: a } \\
\text { number of single concepts emanating from one concept. Score } 1 \text { point for each concept in the group; (II) open grouping: } \\
\text { three or more concepts that are linked in a single chain. Score } 2 \text { points for each concept in the group; (III) closed grouping: } \\
\text { concepts that form a closed system (a loop). Score } 3 \text { points for each concept in the group. }\end{array}$ \\
\hline Hierarchy & $\begin{array}{l}\text { Concepts on a map can be represented as a hierarchical structure in which the more general, more inclusive concepts are at } \\
\text { the top of the map; the specific and exclusive concepts are at the lower end of the map. Concept hierarchy is based upon the } \\
\text { extent that concepts are present in "assigned levels" (as designated by the instructor). Score } 4 \text { points are given to each } \\
\text { concept correctly assigned to a level; Score } 2 \text { points for each concept on a level one-removed from an assigned level; and } \\
\text { no score for concepts that are on a level two or more levels removed from the assigned level. }\end{array}$ \\
\hline Branching & $\begin{array}{l}\text { Branching of concepts refers to the level of differentiation among concepts, that is, the extent the more specific concepts are } \\
\text { connected to more general concepts. Score } 1 \text { point for each branching point that has at least two statement lines. }\end{array}$ \\
\hline Proposition & $\begin{array}{l}\text { Relationships between concepts are represented by connecting word(s) and phrases written on the line joining any two } \\
\text { concepts. (I) a Simple Proposition is a simple English word or phrase. Score } \mathbf{1} \text { point for each word or phrase; give a half for } \\
\text { repeated use of Simple Propositions; (II) a Scientific Proposition is a phrase or statement that is composed of technical or } \\
\text { scientific word(s). Score } 2 \text { points for each proposition; give } 1 \text { point for repeated use of Scientific Proposition. }\end{array}$ \\
\hline
\end{tabular}

Source: Cronin, Dekker and Dunn (1982).

Table 3. NCSEC Model

\begin{tabular}{|c|c|c|c|c|}
\hline Criteria & Exemplary & Exceeds Standard & Adequately Meets Standard & Below Standard \\
\hline Structure & $\begin{array}{c}\text { Well organized; } \\
\text { Logical format; } \\
\text { Contains main concepts; } \\
\text { Contains an appropriate number of } \\
\text { concepts; } \\
\text { Map is “treelike” and not stringy; } \\
\text { Follow standard map conventions. }\end{array}$ & $\begin{array}{l}\text { Thoughtfully organized; } \\
\text { Easy to follow most of the time; } \\
\text { Contains most of the main } \\
\text { concepts; } \\
\text { Contains an adequate number of } \\
\text { concepts; } \\
\text { Follows the standard map } \\
\text { conventions. }\end{array}$ & $\begin{array}{l}\text { Somewhat organized; } \\
\text { Somewhat incoherent; } \\
\text { Contains only a few of the main } \\
\text { concepts. }\end{array}$ & $\begin{array}{l}\text { Choppy and } \\
\text { confusing; }\end{array}$ \\
\hline Content & $\begin{array}{l}\text { Linking words demonstrate superior } \\
\text { conceptual understanding; } \\
\text { Links are precisely labelled; }\end{array}$ & $\begin{array}{l}\text { Linking words easy to follow but } \\
\text { at times ideas unclear; } \\
\text { Links are not precisely labelled; }\end{array}$ & $\begin{array}{c}\text { Linking words are clear but present } \\
\text { a flawed rationale; } \\
\text { Links are not labelled; }\end{array}$ & $\begin{array}{l}\text { Difficult to } \\
\text { follow; } \\
\text { No links. }\end{array}$ \\
\hline Cooperation & $\begin{array}{l}\text { Worked extremely well with each; } \\
\text { Respected and complemented each } \\
\text { other ideas. }\end{array}$ & $\begin{array}{l}\text { Worked very with each other; } \\
\text { Worked to get everyone involved. }\end{array}$ & $\begin{array}{l}\text { Attempted to work well with others; } \\
\text { At times "off tasks" and not } \\
\text { everyone was actively involved. }\end{array}$ & $\begin{array}{l}\text { Littler or no } \\
\text { teamwork. }\end{array}$ \\
\hline
\end{tabular}

Source: NCSEC (2000).

Table 4. University Minnesota Model

\begin{tabular}{|c|c|c|c|c|c|}
\hline Criteria & Excellent & Good & Adequate & Marginal & Unacceptable \\
\hline Structure & $\begin{array}{l}\text { Non-linear structure that } \\
\text { provides a very complete } \\
\text { picture of your ideas }\end{array}$ & $\begin{array}{l}\text { Non-linear structure that } \\
\text { provides a complete } \\
\text { picture of your ideas }\end{array}$ & $\begin{array}{l}\text { No-linear structure that } \\
\text { provides a picture of } \\
\text { your ideas. }\end{array}$ & $\begin{array}{c}\text { Non-linear structure } \\
\text { that shows some } \\
\text { relationships between } \\
\text { ideas }\end{array}$ & $\begin{array}{l}\text { Inappropriate } \\
\text { structure }\end{array}$ \\
\hline Relationship & $\begin{array}{l}\text { Relative importance of } \\
\text { ideas is indicated and } \\
\text { both simple and complex } \\
\text { relationships are very } \\
\text { effectively mapped. }\end{array}$ & $\begin{array}{l}\text { Relative importance of } \\
\text { ideas is indicated and } \\
\text { relationships are very } \\
\text { effectively mapped. }\end{array}$ & $\begin{array}{l}\text { Relative importance of } \\
\text { ideas is indicated; } \\
\text { relationships are } \\
\text { mapped. }\end{array}$ & $\begin{array}{l}\text { Importance is evident } \\
\text { but not very } \\
\text { distinctive; relations } \\
\text { are somewhat clear } \\
\text { but lacking. }\end{array}$ & $\begin{array}{l}\text { No differentiation } \\
\text { between ideas; no } \\
\text { evidence of } \\
\text { meaningful } \\
\text { relationships. }\end{array}$ \\
\hline Exploratory & $\begin{array}{l}\text { Map shows complex } \\
\text { thinking about the } \\
\text { meaningful relationship } \\
\text { between ideas, themes, } \\
\text { and the framework. }\end{array}$ & $\begin{array}{l}\text { Map shows effective } \\
\text { thinking about the } \\
\text { meaningful relationships } \\
\text { between ideas, themes, } \\
\text { and the framework. }\end{array}$ & $\begin{array}{l}\text { Map shows definite } \\
\text { thinking about } \\
\text { relationships between } \\
\text { ideas, themes, and the } \\
\text { framework. }\end{array}$ & $\begin{array}{l}\text { Map shows some } \\
\text { thinking about } \\
\text { relationships between } \\
\text { ideas, themes, and the } \\
\text { framework. }\end{array}$ & $\begin{array}{c}\text { Thinking process is } \\
\text { not clear. }\end{array}$ \\
\hline Communication & $\begin{array}{c}\text { Information is presented } \\
\text { clearly and allows for a } \\
\text { high level of } \\
\text { understanding. }\end{array}$ & $\begin{array}{l}\text { Information is presented } \\
\text { clearly and allows for a } \\
\text { good level of } \\
\text { understanding. }\end{array}$ & $\begin{array}{c}\text { Information is } \\
\text { presented clearly and } \\
\text { allows for a basic level } \\
\text { of understanding. }\end{array}$ & $\begin{array}{c}\text { Information is } \\
\text { presented and some } \\
\text { understanding can be } \\
\text { gained. }\end{array}$ & $\begin{array}{l}\text { Information is not } \\
\text { clear, very difficult } \\
\text { to understand. }\end{array}$ \\
\hline
\end{tabular}

Source: Adapted from University Minnesota (2004).

Table 5. Novak and Gowin Model

\begin{tabular}{ll}
\hline Criteria & \multicolumn{1}{c}{ Description } \\
\hline Propositions & $\begin{array}{l}\text { Is the relationship between two concepts indicated by a connecting line and linking word(s)? Is the relationship valid? For } \\
\text { each meaningful, valid proposition shown. Score } \mathbf{1} \text { point. }\end{array}$ \\
\hline Hierarchy & $\begin{array}{l}\text { Does the map show hierarchy? Is each subordinate concept more specific and less general that the concept above it (in the } \\
\text { context of the material being mapped)? Score } 5 \text { points for each valid level of the hierarchy. }\end{array}$ \\
\hline Cross Links & $\begin{array}{l}\text { Does the map show meaningful connections between one segment of the concept hierarchy and another segment? Is the } \\
\text { relationship shown significant and valid? Score } \mathbf{1 0} \text { points for each cross link that is both valid and significant and } \mathbf{2} \text { points } \\
\text { for each cross link is valid, but does not illustrate a synthesis between sets of related concepts or propositions. Unique or } \\
\text { creative cross link might receive special recognition or extra points. }\end{array}$ \\
\hline Examples & Specific events or objects that are valid instances of those designated by the concept label can be scoring $\mathbf{1}$ point each. \\
\hline
\end{tabular}

Source: Novak and Gowin (1984). 
The first model prepared by Bartels [2] established three assessment parameters: concepts and terminology; knowledge of the relationships between concepts; and ability to communicate through concepts maps, as follows in Table 1. The second model is from Cronin, Dekker and Dunn [5], and has a structure very similar to Novak and Gowin [14]: concepts; grouping; hierarchy, branching and proposition, as follows in Table 2. The third model was prepared by the National Computation Science Education Consortium [11] from Louisiana, United States. This model evaluates the conceptual map based on three components: structure, content and cooperation, as follows in Table 3. The fourth model was prepared by University of Minnesota [16], where the assessment considers five scales: structure, relationship, exploratory and communication, as follows in Table 4. The fifth model was designed by Novak and Gowin [14] and refers as scoring criteria for concept maps. Nevertheless, this model is structured in four levels: propositions; hierarchy; cross links; and examples, as follows in Table 5. The sixth model, built by McMurray [7], is based on Novak and Gowin [14] model. The assessment model has six parameters: breadth, interconnectivity, use of descriptive links, efficiency of links, layout, development over time, as follows in Table 6. Finally, Mueller [10], who developed the seventh assessment model concept map. The author has established four assessment parameters: legible, accurate, complete, and sophisticated, as follows in Table 7.

Table 6. McMurray Model

\begin{tabular}{|c|c|c|c|c|}
\hline Criteria & Exemplary & Good & Acceptable & Unacceptable \\
\hline Breadth & $\begin{array}{l}\text { Map includes the important } \\
\text { concepts and describes domain } \\
\text { on multiple levels. }\end{array}$ & $\begin{array}{l}\text { Map includes most important } \\
\text { concepts; describes domain on } \\
\text { limited number of levels. }\end{array}$ & $\begin{array}{l}\text { Important concepts missing } \\
\text { and/or describes domain on } \\
\text { only one level. }\end{array}$ & $\begin{array}{l}\text { Map includes minimum } \\
\text { concepts with many } \\
\text { important concepts } \\
\text { missing. } \\
\end{array}$ \\
\hline Interconnectivity & $\begin{array}{l}\text { All concepts interlinked with } \\
\text { several other. }\end{array}$ & $\begin{array}{l}\text { Most concepts interlinked with } \\
\text { other concepts. }\end{array}$ & $\begin{array}{c}\text { Several concepts linked to } \\
\text { other concepts. }\end{array}$ & $\begin{array}{l}\text { Few concepts linked to } \\
\text { other concepts. }\end{array}$ \\
\hline $\begin{array}{l}\text { Use of } \\
\text { Descriptive } \\
\text { Links }\end{array}$ & $\begin{array}{l}\text { Links succinctly and } \\
\text { accurately describe all } \\
\text { relationships. }\end{array}$ & $\begin{array}{l}\text { Links are descriptive and valid } \\
\text { for most relationships. }\end{array}$ & $\begin{array}{l}\text { Some links unclear or vague; } \\
\text { some invalid or unclear. }\end{array}$ & $\begin{array}{c}\text { Links are vague; show } \\
\text { inconsistent relationships. }\end{array}$ \\
\hline $\begin{array}{l}\text { Efficiency of } \\
\quad \text { Links }\end{array}$ & $\begin{array}{l}\text { Each link type is distinct from } \\
\text { all others, clearly describes } \\
\text { relationship; used consistently. }\end{array}$ & $\begin{array}{l}\text { Most links are distinct from } \\
\text { others; discriminate concepts; } \\
\text { present variety of relationships; } \\
\text { used fairly consistently. }\end{array}$ & $\begin{array}{l}\text { Several links are } \\
\text { synonymous; do not } \\
\text { discriminate concepts well; } \\
\text { do not show a variety of } \\
\text { relationships; used } \\
\text { inconsistently. }\end{array}$ & $\begin{array}{l}\text { Most links synonymous or } \\
\text { vaguely describe } \\
\text { relationships and are not } \\
\text { distinct from other links. }\end{array}$ \\
\hline Layout & $\begin{array}{l}\text { Map is contained in a single } \\
\text { page, has multiple clear } \\
\text { hierarchies, is well laid out } \\
\text { and provides a sufficient } \\
\text { number of relevant examples } \\
\text { with links. }\end{array}$ & $\begin{array}{l}\text { Map is contained in a single } \\
\text { page, has multiple clear } \\
\text { hierarchies, is fairly well laid } \\
\text { out and provides a sufficient } \\
\text { number of fairly relevant } \\
\text { examples with links. }\end{array}$ & $\begin{array}{l}\text { Map is not contained in a } \\
\text { single page, has unclear } \\
\text { hierarchies, is poorly laid out } \\
\text { and provides some fairly } \\
\text { relevant examples with links. }\end{array}$ & $\begin{array}{l}\text { Map is not contained in a } \\
\text { single page, is confusing to } \\
\text { read with no hierarchical } \\
\text { organizations. }\end{array}$ \\
\hline $\begin{array}{l}\text { Development } \\
\text { Over Time }\end{array}$ & $\begin{array}{l}\text { Final map shows considerable } \\
\text { cognitive progression from } \\
\text { base map and a significantly } \\
\text { greater depth of understanding } \\
\text { of the domain. }\end{array}$ & $\begin{array}{l}\text { Final map shows some } \\
\text { cognitive progression from base } \\
\text { map and a somewhat greater } \\
\text { depth of understanding of the } \\
\text { domain. }\end{array}$ & $\begin{array}{l}\text { Final map shows minimal } \\
\text { cognitive progression from } \\
\text { base map and a slightly } \\
\text { greater depth of } \\
\text { understanding of the domain. }\end{array}$ & $\begin{array}{l}\text { Final map shows no } \\
\text { significant cognitive } \\
\text { progression from base map } \\
\text { and no increase in the } \\
\text { understanding of the } \\
\text { domain. }\end{array}$ \\
\hline
\end{tabular}

Source: McMurray (2014)

Table 7. Mueller Model

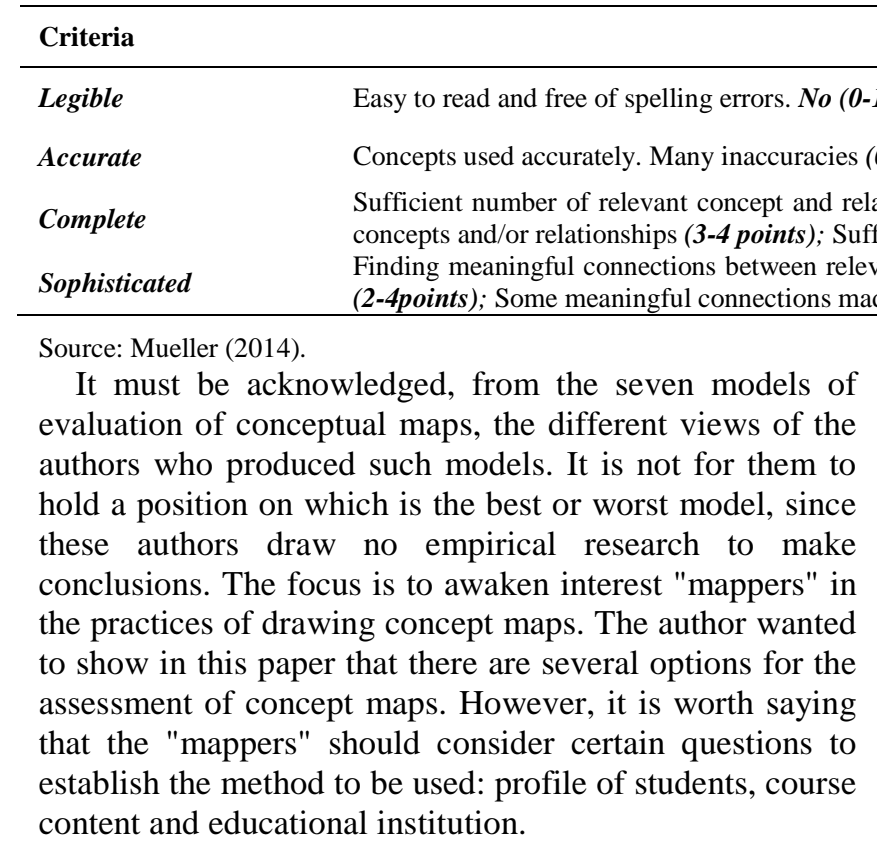

Description

Criteria

;Yes (2 points)

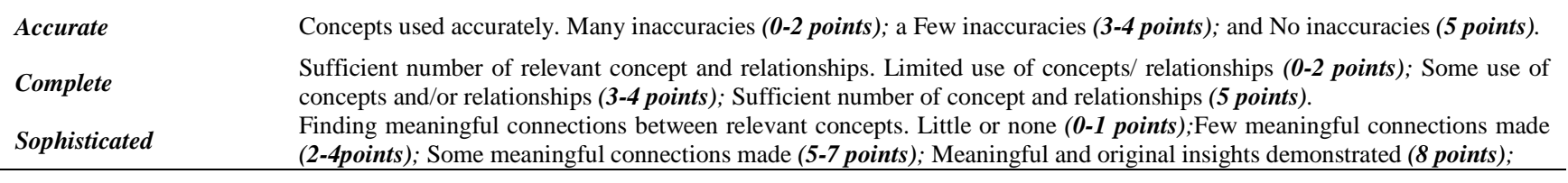

ource: Mueller (2014).

It must be acknowledged, from the seven models of evaluation of conceptual maps, the different views of the authors who produced such models. It is not for them to hold a position on which is the best or worst model, since these authors draw no empirical research to make conclusions. The focus is to awaken interest "mappers" in the practices of drawing concept maps. The author wanted sher in this paper that there are several options for the that the "mappers" should consider certain questions to content and educational institution.

\section{Final Considerations}

It is clear in this paper that the concept maps are: (I) effective in identifying valid and invalid ideas; (II) understood as knowledge in construction, because they fit into a social constructivist-interactionist perspective; (III) tools for sequentially organize content using ideas from progressive differentiation (those dealing inclusive) and integrative reconciliation (delineating similarities and differences between the selected ideas); (IV) concepts and 
threads that should be explained by those who make them, because the author is externalizing meanings; (V) flexible instruments that can be used in several situations and purposes; (VI) effective for focusing the content expected to be learned; (VII) applied to students who already have some familiarity with the content, because then they will be able to realize the integration, reconciliation and differentiation of meanings; (VIII) dynamic, since it reflects the understanding from who does it and when does it. So while the concept map works with several progressive ideas to achieve a concept, the mind map follows several pathways targeted by an idea.

Regardless of the model assessment of concept maps chosen by the educator, they should be used to assist students to enhance their maps and, consequently, their knowledge on a specific topic. This paper does not have the purpose to point out what is the best and the worst model, but rather to relate the reference parameters used to assess the concept maps. It was observed that there are models: broader; more complete, with better scales or evaluation categories; and some that contains parameters redundant. However, in general, one might note that all models use some ordinary parameters in order to assess: (I) the progressive organization of the concepts; (II) the concept network of relationship or built ideas; (III) the words or phrases that will concatenate the concepts cognitive, map the visual aspects, which relate to how the student communicates; (IV) and how the concepts maps can be clear, concise and explained descriptively from the characteristics about the subject. As much as the above assessment models are available, nothing prevents an educational professional might prepare their own model. Nevertheless, it worth mentioning that the concept maps are idiosyncratic nature; thus lets open up new possibilities for its assessment. In summary, assessment model must come from learning expectations that the educator expect with regards its students.

Wherefore, to say what is the best or the worst assessment model of concept maps would be premature and reckless in this paper, since it would fit an empirical study on institutions and courses to conduct plausible explanations from what the best way to assess a conceptual map, even though Cronin, Dekker and Dunn [5], University of Minnesota [16] and McMurray [7] models include a larger number of dimensions for the assessments. Therefore, we suggest future studies to test the models presented in this paper, to know, in fact, which one(s) is(are) considered the most appropriate(s) to assess the concept maps produced by students.

\section{References}

[1] Ausubel, D. P. (2000). Aquisição e retenção de conhecimentos: uma perspectiva cognitiva. Lisboa: Paralelo.

[2] Bartels, B. H. (1995). Promoting mathematics connections with concept mapping. Mathematics Teaching in the Middle School, 1(7), 542-549.

[3] Buzan, T. (2005). Mapas mentais e sua elaboração. São Paulo: Cutrix.

[4] Buzan, T. \& Buzan, B. (1993). The mind map book: how to use radiante thinking to maximize your brain's untapped potential. New York: Plume.

[5] Cronin, P. J., Dekker, J. \& Dunn, J. G. (1982). A procedure for using and evaluating concept maps. Research in Science Education, 12(1), 17-24.

[6] Fodor, J. A. (1999). Conceptos: donde la ciencia cognitiva se equivocó. Barcelona: Gedisa.

[7] McMurray, J. (2014). Rubric for assessing concept maps. University of Waterloo, California, available in https://uwaterloo.ca/centre-for-teaching-excellence/teachingresources/teaching-tips/assessing-student-work/grading-andfeedback/rubric-assessing-concept-maps. [accessed in 05/02/2014].

[8] Moreira, A. M. (2002). A teoria dos campos conceituais de Vergnaud, o Ensino de ciências e a pesquisa nesta área. Investigações em Ensino de Ciência, 7(1), 7-29.

[9] Moreira, M. A. (2010). Mapas conceituais e aprendizagem significativa. São Paulo: Centauro.

[10] Mueller, J. Concept map, available in: http://jonathan.mueller.faculty.noctrl.edu/240/conceptmaprubric.ht $\mathrm{m}$. [accessed in 05/02/2014].

[11] National Computation Science Education Consortium Louisiana Team 11. (2000). Concept map, available in: http://www.ncsec.org/team11/RubricConceptMap.doc. [accessed in $05 / 02 / 2014]$.

[12] Novak, J. D. \& Cañas, A. J. (2007). Theoretical origins of concept maps, how to construct them, and uses in education. Reflecting Education, London, 3(1), 29-42.

[13] Novak, J. D. \& Cañas, A. J. (2010). A teoria subjacente aos mapas conceituais e como elaborá-los e usá-los. Práxis Educativa, Ponta Grossa, 5(1), 9-29.

[14] Novak, J. D. \& Gowin, D. B. (1984). Learning how to learn. New York: Cambridge University Press.

[15] Oliveira, M. M. \& Frota, P. R. O. (2012). Mapas conceituais como estratégias para o ensino de educação ambiental. Atos de Pesquisa em Educação, Universidade Regional de Blumenau, 7(1), 228-241.

[16] University of Minnesota Digital Media Center (2004). Concept map, available in:

http://dmc.umn.edu/activities/mindmap/assessment.pdf. [accessed in 05/02/2014].

[17] Vergnaud. G. (1990). La théorie des champs conceptuels. Recherches en Didactique des Mathématiques, 10(23), 133-170.

[18] Villalon, J. \& Calvo, R. A. (2011). Concept maps as cognitive visualizations of writing assignment. Educational Technology \& Society, 14(3), 16-27. 